\title{
Role of the AGA/AGG codons, the rarest codons in global gene expression in Escherichia coli
}

\author{
Gia-Fen T. Chen and Masayori Inouye \\ Department of Biochemistry, Robert Wood Johnson Medical School, Piscataway, New Jersey 08854 USA
}

\begin{abstract}
AGA and AGG codons for arginine are the least used codons in Escherichia coli. Previous findings have shown that these codons are used preferentially within the first 25 codons in $E$. coli genes. More than 100 genes having a single AGA/AGG codon within the first 25 codons were identified to be associated with various essential cellular functions. The lacZ gene, containing 5 AGG codons after the tenth codon from the initiation codon, was constructed as a model system. The production of $\beta$-galactosidase was inhibited almost completely during the stationary phase, whereas the production of the control $\beta$-galactosidase without AGG codons was not. The inhibitory effect by the 5 AGG codons was substantially suppressed either by coexpressing the argU gene for tRNA Arg UCU/CCU $_{\text {or }}$ by moving the 5 AGG codons by $>50$ codons away from the initiation codon. In addition, the production of a number of proteins resolved by two-dimensional gel electrophoresis was enhanced significantly during the stationary phase in the cells harboring a plasmid containing argU. At least one of them was identified as the hns product encoded by an ORF having an AGA codon at the nineteenth position. On the basis of these results, it is proposed that the expression of a group of essential genes for various cellular functions that have a single AGA/AGG codon very close to the initiation codon are globally regulated by the availability of the least abundant tRNA $\mathrm{ACE}_{\mathrm{U}}^{\mathrm{Arg}} \mathrm{CCU}$. A model for this regulation is proposed.
\end{abstract}

[Key Words: Codon usage; ribosome; translation growth rate; tRNA]

Received April 13, 1994; revised version accepted September 1, 1994.

In various organisms, some synonymous codons are used more frequently than others. Such nonrandom usage of synonymous codons has been well documented and shown to correlate with the relative quantities of individual tRNAs (Ikemura 1981a,b; Maruyama et al. 1986). It has been suggested that genes encoding abundant protein species selectively use the "optimal codon" or major codons as determined by the abundance of isoaccepting tRNA (Ikemura 1981a). However, it has not been established whether the codon usage determines the rate of protein synthesis or whether the rate of protein synthesis under normal growth conditions is simply determined by the rate of translation initiation and not affected by different rates of translation at different codons (Sørensen and Pedersen 1989; Sørensen et al. 1990; for review, see Anderson and Kurland 1990).

To elucidate the role of minor codons in gene expression in Escherichia coli, we had previously examined the distribution of minor codons within a gene and found that minor codons such as AGA, AGG, CUA, UCA, AGU, ACA, GGA, CCC, and AUA are used preferentially within the first 25 codons (Chen and Inouye 1990). Among the genes containing a single AGA/AGG codon, the least used codon in $E$. coli within the first 25 codons, we found a number of key genes essential for various cellular functions, such as genes for single-stranded DNA-binding protein, ribosomal S10 protein, some tRNA synthetases, adenylate cyclase, LexA, integration host factor (IHF), SecY, FtsA, and ribonuclease $\mathrm{P}$ (Inouye and Chen 1990). On the basis of these analyses, we proposed that the rate of translation at the minor codons decreases as a result of limited availability of charged tRNAs for the minor codons when cell growth slows down. This causes ribosome stalling at a minor codon. If such a translational pause is located closer to the initiation codon, then a queue of ribosomes may form after the minor codon, thereby inhibiting the effective entry of a ribosome at the initiation site.

This hypothesis, the minor codon modulator hypothesis, may explain the preferential localization of minor codons within the first 25 codons in $E$. coli genes, which may globally regulate the expression of a number of key genes and by cellular functions under growth rate-limiting conditions (Inouye and Chen 1990). We have experimentally explored the validity of this hypothesis /Chen and Inouye 1990). Five AGG codons were inserted after the tenth codon downstream of the initiation codon of the lac $Z$ gene. In this case, production of $\beta$-galactosidase was ceased completely after a mid-log phase of cell growth; in contrast, the lacZ gene with five CGU 
codons, a major codon for arginine, was expressed during this growth phase. However, $\beta$-galactosidase production increased linearly, almost to the level of the control $\beta$-galactosidase, as a function of increased distance between the site of the AGG codons and the initiation codon (Chen and Inouye 1990). This result is consistent with the minor codon modulator hypothesis.

In this paper we first reexamined the distribution of the AGA/AGG codons in $E$. coli genes using a much larger data bank-3540 polypeptides in contrast to the earlier 678 polypeptides (Chen and Inouye 1990)-and confirmed the previous conclusion concerning the preferential AGA/AGG usage within the first 25 codons. Then, to prove unambiguously the role of the minor codons, we measured the synthesis of $\beta$-galactosidases from various genes with and without the AGG codons by $\left[{ }^{35} S\right]$ methionine incorporation. We demonstrate that the inhibitory effect of the five AGG codons in the lacZ gene during the stationary phase can be suppressed either by overproduction of tRNA for the minor codon or by moving the AGG site away from the initiation codon. In addition, the production of a number of proteins was enhanced significantly during the stationary phase in the cells with a plasmid harboring the gene for

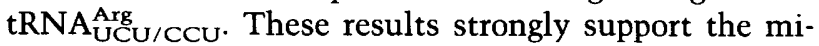
nor codon modulator hypothesis and the important role of minor codons in global regulation of cellular functions in $E$. coli.

It has been shown from the analysis of the codon adaptation index of $E$. coli genes that codon usage bias is weaker at the start of the gene than elsewhere (Bulmer 1988; Eyre-Walker and Bulmer 1993). This tendency is particularly significant for those genes that are highly expressed. Although these results are consistent with our conclusion (Chen and Inouye 1990; this paper), these investigators proposed that preferential minor codon usage near the start of the gene is to avoid mRNA secondary structures around the initiation codon but not to play a role in gene regulation, as we have proposed earlier (Chen and Inouye 1990; Inouye and Chen 1990). On the basis of our previous and present experimental results, we argue that their hypothesis is unlikely and that minor codons play more active roles in the regulation of gene expression.

\section{Results}

Location-dependent usage of the AGA/AGG codon in $\mathrm{E}$. coli genes

Previously, we have examined 678 polypeptides of $E$. coli available in GenBank at that time for the usage of AGA/ AGG codons (Chen and Inouye 1990). Since then, sequences of many more polypeptides have been determined. In this study we reexamined the usage of AGA/ AGG codons using 3540 polypeptides currently available in the data base (GenBank, Release 80; EMBL, Release 37, December 1993). Of these, 2105 have no AGA/AGG codons. In the remaining 1435 polypeptides, 1363 are larger than 50 residues. Of the 1363 polypeptides, 620 contain only one AGA or AGG codon and 743 contain more than one AGA/AGG codon. As shown previously (Chen and Inouye 1990), the frequency of (AGA + AGG) codon usage for every 25 codons from the initiation codon up to the 250th codon was calculated in two different ways. First, the frequency of the AGA/AGG usage was expressed as a fraction of the total arginine codons (CGU, CGC, CGA, CGG, AGA, and AGG) within a unit of 25 codons as shown by stippled bars in Figure 1 . This fraction is defined as $(n / N)$, where $n$ is the total number of (AGA + AGG) codons within a unit of 25 amino acid residues and $N$ is the total number of arginine codons within the same unit. Second, the frequency of the AGA/AGG usage for each 25 codons was calculated as a fraction of the total AGA/AGG codons used within the first 250 codons from the initiation codon. These frequencies are expressed with hatched bars in Figure 1.

As shown in Figure 1A, by both stippled and hatched bars, AGA and AGG codons are used more frequently within the first 25 codons. This high frequency within the first 25 codons becomes much more significant when those proteins that have only one AGA or AGG codon are analyzed, as shown in Figure 1B. The minor codon is used three to four times more frequently within the first 25 codons than any other parts of the polypeptides. Of 620 polypeptides containing only one AGA or AGG codon, $129(20.8 \%)$ have the minor codon within the first 25 codons. In contrast to these polypeptides, those that have more than one AGA/AGG codon were found to contain the minor codons quite randomly throughout the entire polypeptide (Fig. 1C). This is particularly evident with the stippled bars. These results confirmed our previous conclusions, obtained from a smaller sample size; whenever the AGA/AGG codon is used only once in an E. coli gene, it is preferentially used within the first 25 codons from the initiation codon (Chen and Inouye 1990; Inouye and Chen 1990). All genes having a single AGA/AGG codon within the first 25 codons are classified by their functions and listed in Table 1, where the total number of amino acid residues for each protein, the total number of arginine residues used in the protein, and the position of the single AGA/AGG codon from the amino-terminal end are indicated. The analysis of Table 1 will be discussed later, in the Discussion, on the basis of our previous hypothesis designated Minor codon modulator hypothesis (Inouye and Chen 1990).

\section{Suppression of the inhibitory effect of five $A G G$ codons in lacZ by $t R N A$ overproduction}

Previously, we have shown that the insertion of five AGG codons at the eleventh codon substantially reduced the production of $\beta$-galactosidase during the stationary growth phase (Chen and Inouye 1990). E. coli SB4288 cells harboring pIT-lacl or pIT-lac1-AGG5 grew almost identically as shown in Figure 2A. In both cases, cell growth stopped after $5 \mathrm{hr}$ and very little increase in the optical density was observed during the next $17.5 \mathrm{hr}$ of incubation. However, during the stationary phase, the $\beta$-galactosidase activity steadily increased to $\sim 95,000$ 


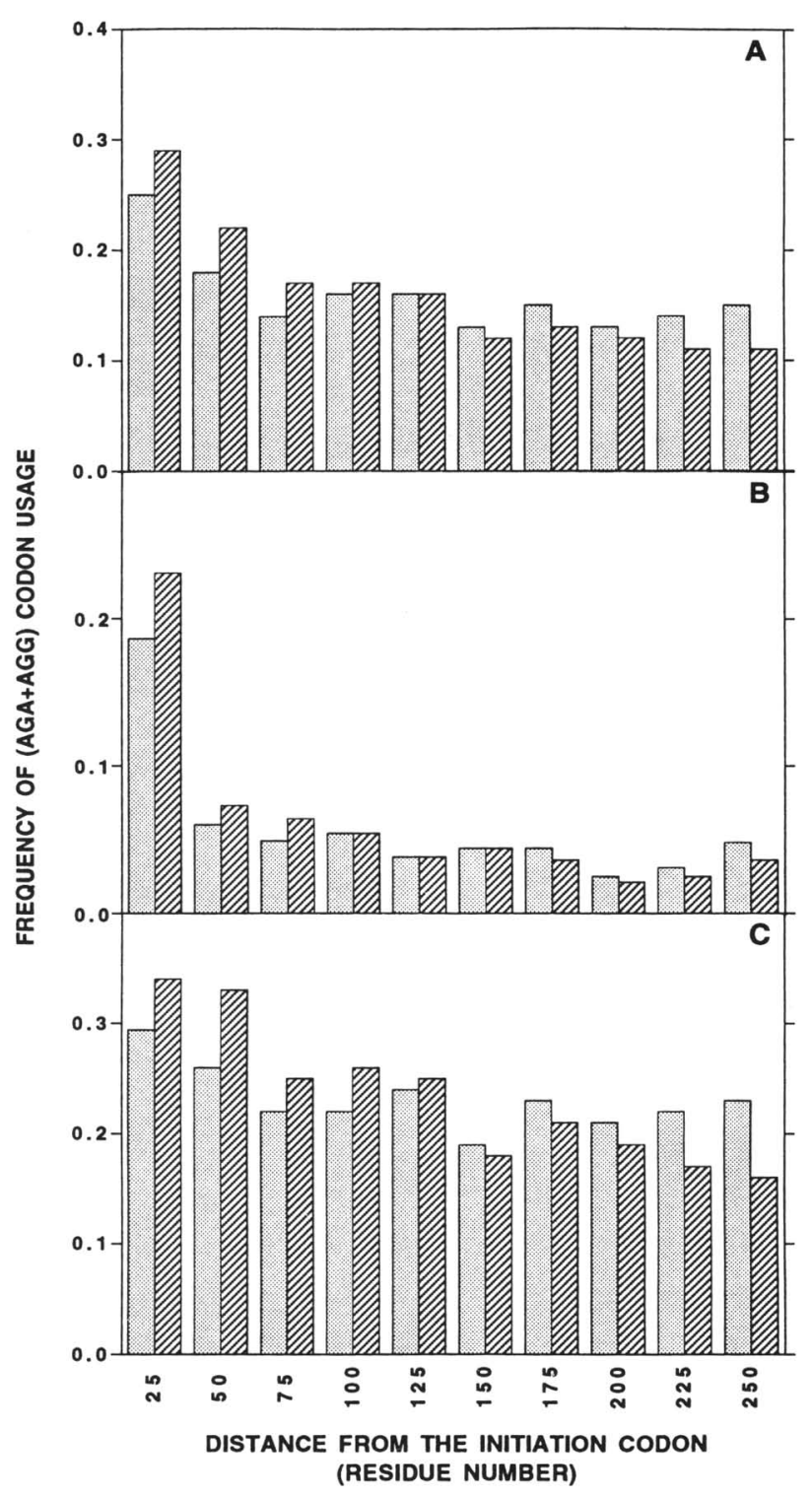

Figure 1. Frequency of AGA and AGG codons usage in E. coli. The positions of AGA/AGG codons in 2557 different $E$. coli genes available in GenBank (Release 80), EMBL (Release 37), (December 1993) were analyzed as described previously (Chen and Inouye 1990). Of 3540 polypeptides encoded by these loci, 2105 proteins lack both AGA and AGG codons. Among the remaining 1435,1363 polypeptides consist of $>50$ amino acid residues, and of these 1363 polypeptides $(A), 620$ have either a single AGA or AGG codon $(B)$; and the other 743 have more than one AGA/AGG codon $(C)$. Each group of proteins was analyzed for the frequency of $\{A G A+A G G\}$ codon usage for every 25 amino acid residues from the amino-terminal ends. The frequencies indicated by stippled bars represent those defined as $(n / N)$, where $n$ is the total number of (AGA + AGA) codons within a unit of 25 codons and $N$ is the total number of arginine codons within the same unit. The frequencies indicated by hatched bars represent those calculated as a fraction of the total AGA/AGG codons used within the first 250 codons.

units in the case of the cells harboring pIT-lacl. On the other hand, the cells harboring pIT-lac1-AGG5 were un- able to produce $\beta$-galactosidase at all during the stationary phase. However, cells harboring the construct pITlacl-CGU5, in which five AGG codons on pIT-laclAGG5 were substituted with five CGU codons (a major codon for arginine) (Chen and Inouye 1990), became capable of producing the enzyme again during the stationary phase (Fig. 2B).

Previously, the dramatic effect of the insertion of five AGG codons at the eleventh codon of the lacZ gene was postulated to arise from the severe limitation of tRNA for the AGG codon, which causes ribosomes to stall at the minor codons (Inouye and Chen 1990). A queue of stalling ribosomes was proposed to form nearby the initiation codon so that the entry of a new ribosome is blocked. On the basis of this model, one can predict that this blockage can be eliminated by overproducing the minor tRNA. This is the case as shown in Figure 2B: Whereas lacZ-AGG5 expression was inhibited almost completely in the cells with pIT-lacl-AGG5, recovery from this inhibition was obtained using pIT-lacl-AGG5 [(lpp $p^{p}$ argU-AGA], which contains the $\arg U$ gene in conjunction with lacZ-AGG5. The arg $U$ gene decodes

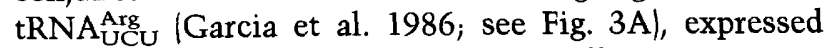
under the constitutive lpp promoter. Cells carrying pITlac1-AGG5 [(lpp $\left.{ }^{p} \mid \arg U-A G A\right]$ (Fig. 3B) grew as well as control cells (Fig. 2A), and the production of $\beta$-galactosidase was found to continue during the stationary phase, although the rate of the production was approximately one third of that with pIT-lacl-CGU5 (Fig. 2B). As a control, pIT-lacl-CGU5 [(lpp $\left.p^{p} \arg U-\mathrm{AGA}\right]$ was constructed. It was found that the $\arg U$ gene had no effect on the expression of the lacZ gene with five CGU codons in any growth phases (data not shown).

\section{Biosynthesis of $\beta$-galactosidase}

To demonstrate unambiguously that $\beta$-galactosidase was synthesized de novo during the stationary phase by the overproduction of tRNA $\mathrm{Arg}$, cells were grown at $37^{\circ} \mathrm{C}$ to the stationary phase. Figure 4 shows the protein patterns of cells at $22 \mathrm{hr}$ after the addition of $2 \mathrm{mM}$ IPTG. $\beta$-Galactosidase from lacZ-AGG5 is barely detected in the cells carrying pIT-lac1-AGG5 (lane 1), whereas its level increased substantially when the $\arg U$ gene was cloned into the same plasmid (lane 2). Notably, we also confirmed our previous observation (lane 3 ) that the inhibitory effect of the five-AGG insertion in the lacZ gene was suppressed simply by adding linkers between the initiation codon and the AGG insertion site (Chen and Inouye 1990). The lacZ gene used in lane 3 contained eight linkers, each of which consisted of 18 nucleotides in size (equivalent to 6 amino acid residues). Therefore, a total of 48 extra amino acid residues were added to $\beta$-galactosidase between the initiator methionine and the consecutive arginine residues. Note that as a result of the insertion, the $\beta$-galactosidase band migrates a little slower in the gel, indicating that there is no abnormal translational event at the five-AGG site (lane 3). Importantly, the insertion of the linkers resulted in the pro- 
Chen and Inouye

Table 1. Genes containing only one AGA or AGG codon that exists within the first 25 codons

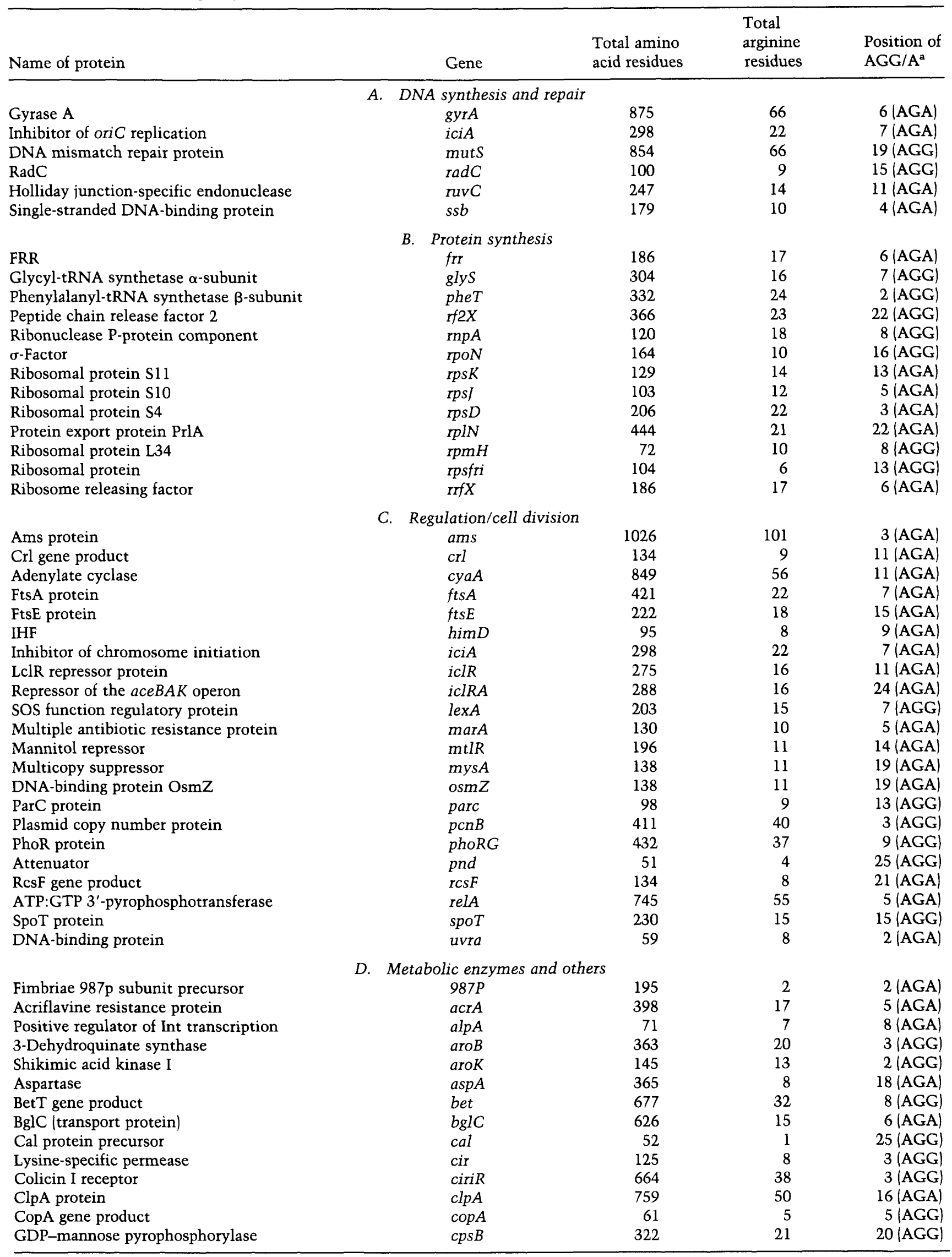


Table 1. (Continued)

\begin{tabular}{|c|c|c|c|c|}
\hline Name of protein & Gene & $\begin{array}{l}\text { Total amino } \\
\text { acid residues }\end{array}$ & $\begin{array}{l}\text { Total } \\
\text { arginine } \\
\text { residues }\end{array}$ & $\begin{array}{l}\text { Position of } \\
\text { AGG/A }\end{array}$ \\
\hline CscB protein & $\csc B$ & 416 & 11 & 8 (AGG) \\
\hline CssA & $\operatorname{css} A$ & 155 & 3 & 19 (AGA) \\
\hline CysT & cys & 278 & 12 & 7 (AGA) \\
\hline Serine acetyltransferase & cys $E$ & 274 & 12 & 18 (AGA) \\
\hline DacB & $d a c B$ & 478 & 26 & 5 (AGA) \\
\hline Deoxycytidine triphosphate deaminase & $d c d$ & 200 & 17 & 2 (AGA) \\
\hline Presumed ATP-dependent RNA helicase & deaD & 572 & 61 & 13 (AGG) \\
\hline DNA damage-inducible protein & $\operatorname{din} F$ & 460 & 26 & 15 (AGG) \\
\hline EBG repressor & $e b g R$ & 328 & 20 & 20 (AGG) \\
\hline EnvA protein & envA & 306 & 18 & 5 (AGG) \\
\hline EnvZ protein & envZ & 451 & 34 & 2 (AGG) \\
\hline Fimbrial subunit F107 & $f 107$ & 171 & 1 & 3 (AGA) \\
\hline Fdv protein & $f d v$ & 854 & 66 & 19 (AGG) \\
\hline FhuE precursor protein & fhuE & 729 & 34 & 8 (AGG) \\
\hline 1-Phosphofructokinase & fruK & 313 & 18 & 3 (AGA) \\
\hline 1,2-Propanediol oxidoreductase & fucO & 384 & 17 & $5(\mathrm{AGA})$. \\
\hline L-Fucose utilization protein & fucP & 438 & 12 & 22 (AGA) \\
\hline Glutamate decarboxylase & $\operatorname{gad} B$ & 467 & 26 & 10 (AGG) \\
\hline UDP galactose-4-epimerase & gale & 338 & 16 & 2 (AGA) \\
\hline GalI & gall & 121 & 8 & 11 (AGA) \\
\hline$\alpha$-D-Glucosyl-1-phosphate uridylytransferse & galu & 303 & 8 & 21 (AGG) \\
\hline 2-Keto-3-deoxy-6-phosphogluconate adolase & $\operatorname{gar} A$ & 123 & 7 & 8 (AGA) \\
\hline Glyoxylate carboligase & $g c l$ & 594 & 32 & 5 (AGA) \\
\hline Branching enzyme & $g \lg B$ & 729 & 53 & 7 (AGA) \\
\hline Glycerol-3-phosphate dehydrogenase & glpda & 94 & 3 & $4(\mathrm{AGA})$ \\
\hline Succinate dehydrogenase (large subunit) & glt $A$ & 589 & 40 & 6 (AGA) \\
\hline Succinate dehydrogenase (small subunit) & gltA & 239 & 17 & 2 (AGA) \\
\hline Glutamate synthase & glt $B A$ & 272 & 30 & 9 (AGG) \\
\hline Glutamate-1-semialdehyde 2,1-aminomutase & gsaG & 427 & 19 & 2 (AGG) \\
\hline Porphobilinogen synthase & $\operatorname{hem} B$ & 324 & 24 & 23 (AGA) \\
\hline Porphobilinogen deaminase & hemC & 313 & 27 & $7(\mathrm{AGA})$ \\
\hline Urogen III methylase & hemX & 393 & 18 & 15 (AGG) \\
\hline DNA-binding protein $\mathrm{H}-\mathrm{NS}$ & $h n S$ & 138 & 11 & 19 (AGA) \\
\hline Hsn-dependent expression ORF-D & $h s n D$ & 191 & 7 & 22 (AGA) \\
\hline IncC & incC & 79 & 7 & 21 (AGG) \\
\hline InsA peptide & is $1 F$ & 91 & 9 & 7 (AGA) \\
\hline KpsM product & kpsM & 259 & 12 & $3(\mathrm{AGA})$ \\
\hline LuxH & $\operatorname{lux} H$ & 387 & 16 & $3\langle\mathrm{AGA}|$ \\
\hline $1,4-\alpha-D-G l u c a n$ glucanohydrolase & mals & 159 & 6 & 19 (AGA) \\
\hline$\alpha$-Galactosidase & melA & 80 & 3 & 13 (AGA) \\
\hline OSB synthase & menC & 319 & 24 & 22 (AGG) \\
\hline Cell-wall hydrolase & mutI & 446 & 30 & $6(\mathrm{AGA})$ \\
\hline Mysa:ORF1 & Mysa:ORF1 & 303 & 8 & 21 (AGG) \\
\hline$N$-acetylglucosamine transport protein & $\operatorname{nag} B E$ & 649 & 18 & 12 (AGG) \\
\hline NarK protein & nark & 463 & 17 & 9 (AGG) \\
\hline NADH-dependent nitrite reductase & $\operatorname{nir} B C$ & 839 & 55 & 5 (AGA) \\
\hline Nitrite reductase & $n r f A$ & 479 & 21 & 3 (AGG) \\
\hline O-6-alkylguanine-DNA alkyltransferase & ogt & 172 & 14 & 3 (AGA) \\
\hline Oligopeptide-binding protein precursor & oppA & 544 & 16 & $7\langle\mathrm{AGA}\rangle$ \\
\hline OrfA & $\operatorname{orf} A$ & 235 & 24 & 23 (AGA) \\
\hline Oxacillin-resistance protein & oxa2 & 134 & 16 & 8 (AGA) \\
\hline Prepropenicillin acylase & pal & 350 & 15 & $4(\mathrm{AGA})$ \\
\hline L-Isoaspartyl-protein carboxyl-methyltransferase & pcm & 209 & 17 & 4 (AGA) \\
\hline Periplasmic protein & perpl & 202 & 4 & 5 (AGA) \\
\hline PhnE protein & $\operatorname{phn} A Q$ & 277 & 11 & 13 |AGA) \\
\hline Membrane protein & phoE & 133 & 9 & 11 (AGA) \\
\hline Pyridine nucleotide transhydrogenase & pntA & 511 & 18 & $7(\mathrm{AGA})$ \\
\hline Phosphoenolpyruvate synthase & pps & 793 & 48 & 23 (AGG) \\
\hline Proline-betaine transporter & probe & 501 & 19 & 4 (AGG) \\
\hline 5'-Phosphoribosyl-5-amino-imidazole synthetase & purM & 346 & 11 & 25 (AGA) \\
\hline RhlE gene product & rhlE & 161 & 14 & 7 (AGG) \\
\hline
\end{tabular}


Table 1. (Continued)

\begin{tabular}{|c|c|c|c|c|}
\hline Name of protein & Gene & $\begin{array}{l}\text { Total amino } \\
\text { acid residues }\end{array}$ & $\begin{array}{l}\text { Total } \\
\text { arginine } \\
\text { residues }\end{array}$ & $\begin{array}{l}\text { Position of } \\
\text { AGG/A }\end{array}$ \\
\hline Thioredoxin precursor & $r h o B$ & 128 & 3 & 11 (AGG) \\
\hline Rhs repetitive element & rhs C & 69 & 6 & 5 (AGA) \\
\hline Ribonuclease E & rne & 816 & 84 & 3 (AGA) \\
\hline REPA3 reading frame & rsc1 & 61 & 5 & $5(\mathrm{AGG})$ \\
\hline Succinate dehydrogenase flavoprotein subunit & $\operatorname{sdh} A$ & 588 & 40 & 6 (AGA) \\
\hline Succinate dehydrogenase iron-sulfur protein subunit & $s d h B$ & 238 & 17 & 2 (AGA) \\
\hline PrlA polypeptide & $\sec Y$ & 443 & 21 & 22 (AGA) \\
\hline Slp gene product & $\operatorname{slp}$ & 165 & 6 & 7 (AGG) \\
\hline SpdE protein & $s p d E$ & 116 & 5 & $6(\mathrm{AGA})$ \\
\hline TolC product & tolC & 86 & 9 & 13 (AGG) \\
\hline Uracil permease & uraA & 430 & 10 & 11 (AGA) \\
\hline Hemed:ORFX & Uro & 393 & 18 & 15 (AGG) \\
\hline
\end{tabular}

From 2557 genes available in GenBank (Release 80), EMBL (Release 37, December 1993), those proteins that have a size larger than 50 residues contain either a single AGA or AGG codon that exists within the first 25 codons were screened. They are listed under the following subdivisions. $(A)$ DNA synthesis and repair; $(B)$ protein synthesis; $(C)$ regulation/cell division; and $(D)$ metabolic enzymes and others.

${ }^{\text {a}}$ From the initiation codon.

duction of $\beta$-galactosidase almost as high as in the control cells with the lacZ gene without any insertion (pITlac1; lane 5) and with the lacZ gene with five CGU codons (pIT-lacl-CGU5; lane 4). The amount of proteins applied to the gel were equivalent in all cases as verified by the levels of $\beta^{\prime}$ and $\beta$ RNA polymerase subunits (duplex bands) on the top of the gel.

Cells harboring pIT-lac1-AGG5 [(lpp $\left.p^{p} \mid a r g U-A G A\right]$ overproduced tRNA $\mathrm{UCU}_{\mathrm{UCU}}$ as shown in Figure 5. Cells with pIT-lac1-AGG5 [(lpp $p^{p}$ argU-AGA] appear to contain $\sim 50$ times more tRNA ${ }_{\mathrm{UCU}}^{\mathrm{Arg}}$ than the control cells harboring pIT-lacl-AGG5 (cf. lanes 2 and 1, respectively).

\section{Production of $\beta$-galactosidase during the stationary phase}

On the basis of the assay of the $\beta$-galactosidase activity during cell growth shown in Figure 2B, the production of $\beta$-galactosidase in the cells harboring pIT-lacl is fairly constant through the exponential phase to the stationary phase, whereas it stops almost completely at the late exponential phase in the cells harboring pIT-laclAGG5. This was confirmed by pulse-labeling experiments as shown in Figure 6A. In the cells with pIT-lacl, the rates of the $\beta$-galactosidase production are almost the same at 1,2,4, and $6 \mathrm{hr}$ of cell growth (lanes $1,2,3$, and 4 , respectively). In contrast, the rates of the $\beta$-galactosidase production in the cells with pIT-lacl-AGG5 (lanes 5-8) were reduced remarkably at 4 and $6 \mathrm{hr}$ (lanes 7 and 8 , respectively), which agrees with the activity assay shown in Figure 2B.

We again tested the effect of the overproduction of tRNA ${ }^{\mathrm{Arg}}$ on the rate of the $\beta$-galactosidase production at 3 and $5 \mathrm{hr}$ of cell growth. In these experiments we also constructed the mutated $\arg U$ gene in which the anticodon sequence was altered from UCU to CCU (see Fig. $3 \mathrm{~A})$ so that the mutated tRNA is able to decode the AGG codon directly. This tRNA gene was constructed because the tRNA from the argU may be specific for AGA and may not be able to translate the AGG codon efficiently in view of the fact that there is another minor tRNA species for AGG in E. coli (Kiesewetter et al. 1987).

As can be seen in Figure 6B, the inhibitory effect of five AGG codons was clearly suppressed by the overproduction of either tRNA $\mathrm{UCU}_{\mathrm{ACU}}^{\mathrm{Arg}}$ or $\mathrm{RNA}_{\mathrm{CCU}}^{\mathrm{Arg}}$. In particular, at 5 $\mathrm{hr}$, no production of $\beta$-galactosidase with five AGG codons was observed (Fig. 6B, lane 5), whereas remarkable resumption of the $\beta$-galactosidase synthesis occurred as a result of the overproduction of tRNA ${ }^{\text {Arg }}$ (Fig. $6 \mathrm{~B}$, lanes 6,7$)$. It should be noted that no significant difference was observed between tRNA Arg (lane 6) and tRNA $A_{C C U}^{A r g}$ (lane 7), indicating that the anticodon for AGA is able to decode the AGG codon effectively.

\section{Effects of argU on protein production during the stationary phase}

The results described above suggest that the overproduction of tRNAA Arg during the stationary phase may affect the expression of chromosomal genes containing AGA/ AGG codons within the first 25 codons. To examine whether the overproduction of tRNA $\mathrm{ACE}_{\mathrm{UCU}}$ affects protein patterns during the stationary phase, E. coli JM83 with or without the $\arg U$ gene was pulse-labeled with $\left[{ }^{35} S\right]$ methionine during the stationary phase and proteins were separated by two-dimensional gel electrophoresis.

As shown in Figure 7, there are no significant differences in the protein patterns during the exponential phase between the cells without and with the overproduction of the $\arg U$ gene (A and B, respectively). However, when cells were labeled during the stationary phase, a large number of proteins were labeled much more strongly in the cells with the $\arg U$ gene (D) than in the cells without the gene $(\mathrm{C})$. Some of the proteins 


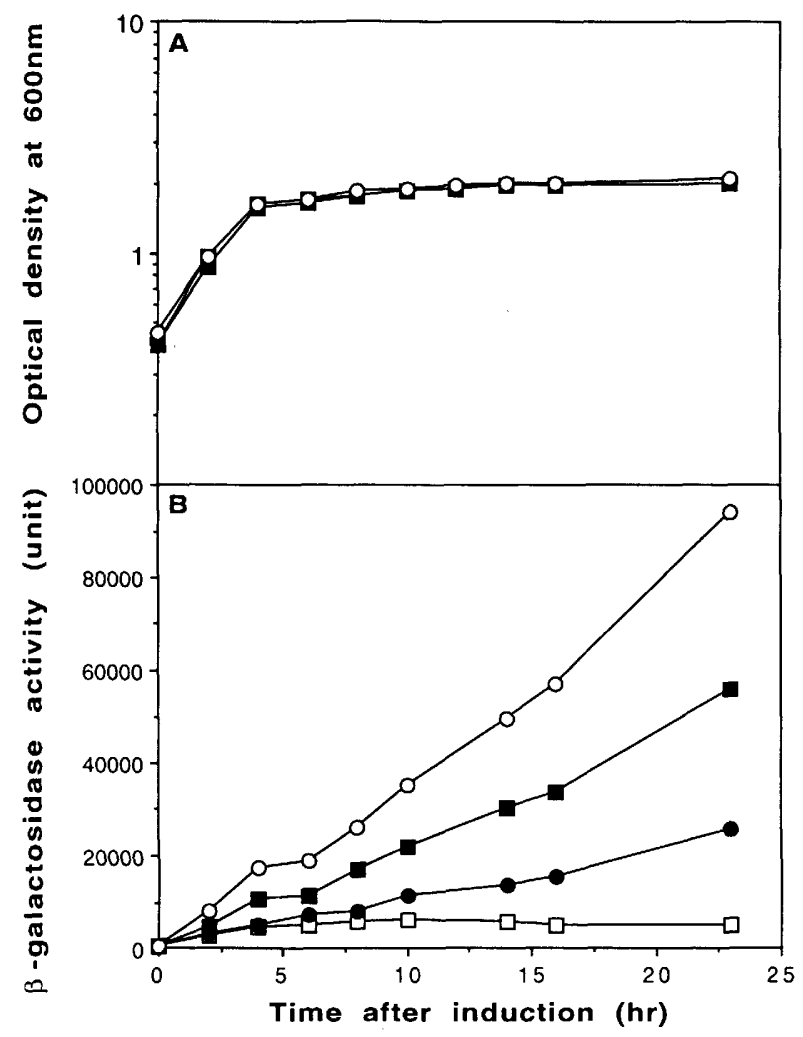

Figure 2. Growth curves and $\beta$-galactosidase production. Growth curves and $\beta$-galactosidase production of cells harboring pIT-lac1-AGG5, pIT-lac1-AGG5 [(1pp $\left.p^{p} \mid \arg U\right]$, pIT-lac1CGU5, and pIT-lacl were compared. E. coli cell SB4288 harboring the following plasmids was grown as described in Materials and methods: pIT-lacl-AGG5, five tandem repeats of the minor arginine codon; pIT-lacl-AGG5 [(lpp $\left.p^{p} \mid \arg U\right]$, the minor codon plus the $\arg U$ gene (decodes minor tRNA Urg $_{\text {I }}$ ); pIT-lac1CGU5, five tandem repeats of major arginine codon (CGU) (Chen and Inouye 1990); or pIT-lacl, a control wild-type plasmid. After induction of $1 a c Z$ expression with 2 mM IPTG, aliquots were taken at the times indicated. $(A)$ Growth curves after the addition of $2 \mathrm{mM}$ IPTG at 0 time; cell growth was measured by a Klett-Summerson colorimeter. $(B) \beta$-Galactosidase activity after the addition of $2 \mathrm{mM}$ IPTG at 0 time was assayed by the procedure of Miller (1972). ( $\square$ ) Cells with pIT-lacl-AGG5; (O)

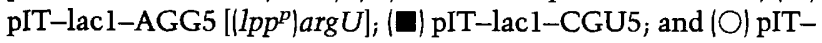
lacl.

whose production was significantly enhanced are circled in Figure 7D. On the basis of well-established two-dimensional gel coordinates of $E$. coli proteins /VanBogelen et al. 1990), the protein at spot 7 was identified as the $h n s$ product. Interestingly, hns contains a single AGA codon at the nineteenth codon (see Table 1), indicating that the overproduction of tRNA $\mathrm{Acu}_{\mathrm{UCU}}^{\mathrm{Arg}}$ in the stationary phase not only affects the expression of genes in plasmids but also of chromosomal genes. However, it is not known at present whether the enhanced production of all the proteins observed in Figure 7D is the result of the direct effect of the overproduction of tRNA Arg $\mathrm{ACU}_{\mathrm{U}}$ at the level of translation of their mRNAs.

\section{Discussion}

Analysis of genes with a single AGA/AGG codon

Of $620 \mathrm{E}$. coli genes containing only one AGA/AGG codon and encoding a polypeptide of $>50$ residues, there are 129 that have the codon within the first 25 codons from the initiation codon. All of these genes are listed in Table 1. The positions of the AGA/AGG codons in these genes are plotted in Figure 8. Interestingly, 55\% of these codons are located between the second and eighth codon, which is much higher than a random distribution of these codons $(7 / 24=29 \%)$. The genes in Table 1 are classified into four groups, depending on their functions; and one can see that among the proteins containing a single AGA/AGG codon within the first 25 codons, there are various essential genes in wide varieties of functions such as (A) a protein required for DNA synthesis (singlestranded DNA-binding protein), (B) many proteins associated with protein synthesis including some aminoacyltRNA synthetases and ribosomal proteins, $(\mathrm{C})$ proteins associated with gene regulation and cell division, such as LexA, IHF, and adenylate cyclase, and (D) a large number of proteins with various metabolic functions.

\section{Minor codon modulator hypothesis}

This study, together with previous results (Chen and Inouye 1990), demonstrates the following points: (1) The insertion of five AGG codons at the eleventh codon of lacZ inhibited its expression severely at the late log and stationary phases of $E$. coli cell growth. (2) The inhibitory effect is decreased when the five AGG codons are moved farther away from the initiation codon. When 48 extra codons (thus, a total of 58 codons from the initiation codon/ are added upstream of the five AGG codons, the inhibitory effect can be suppressed almost completely. (3) The inhibitory effect of the five AGG codons is the result of unavailability of tRNA for the minor codons. The inhibitory effect can be suppressed by the overproduction of the tRNA for the minor codons for arginine during the stationary phase. (4) There are a large number of $E$. coli genes that possess a single AGA/AGG codon preferentially within the first 25 codons from the initiation codon. (5) A number of cellular proteins encoded by chromosomal genes are abnormally overproduced only in the stationary phase in the cells carrying a plasmid with the arg $U$ gene for tRNA $\mathrm{Arg}_{\mathrm{UCU}}$. One of the proteins was identified as Hns, whose gene contains a single AGA codon at the nineteenth position.

We designate these genes described above as primary target genes, which are defined as those genes having AGA/AGG codons within the first 25 codons. On the basis of our experimental evidence, we can safely assume that the expression of the primary target genes is specifically regulated by the concentration of tRNA for minor AGA/AGG codons. The tRNA for the minor codons is known to exist in a very limited amount even in exponentially growing cells (Ikemura 1981). We propose that the expression of the $\arg U$ gene is tightly associated with cell growth in such a way that the concentration of the 




Figure 3. Structure of pIT-lacl-AGG5, $\left[\left(\operatorname{lpp} p^{P} \mid \arg U\right]\right.$. $|A|$ Oligonucleotides used for the construction of wild-type and mutated $\arg U$ genes. The DNA sequence of tRNA UCU $_{\text {Arg }}$ for arginine is from Garcia et al. (1986). The 5'-end G residue and the $3^{\prime}$-end A residue are indicated by solid dots, respectively. The arrows indicate the junction sites between the synthetic oligonucleotides used. Both the $5^{\prime}$ end and the $3^{\prime}$ end of the DNA fragment correspond to the HindIII site. The anticodon sequence TCT of the wild-type $\arg U$ gene for $\mathrm{TRNA}_{\mathrm{UCU}}^{\mathrm{Arg}}$ is underlined. For the mutated $\arg U$ gene, the same oligonucleotides were used except for two central pieces that contain the different anticodon sequence, CCT for tRNA $\mathrm{Arg}$. $(B)$ Structure of pIT-lacl-AGG5 [(lpp $\left.p^{p} \mid \arg U\right]$. The plasmid pIT-lacl-AGG5 was constructed from pIT-lacl as described previously (Chen and Inouye 1990). At the unique Sall site of pIT-lacl-AGG5, the DNA fragment containing the synthetic argU gene (Garcia et al. 1986) was inserted as described in Materials and methods. The resulting plasmid was designated pIT-lacl-AGG5 [(lpp $\left.p^{p} \arg U\right]$. The synthetic $\arg U$ gene is flanked by the synthetic lpp promoter at the $5^{\prime}$ end and the synthetic $r n C$ transcriptional termination signal derived from pGFIBl (Normanly et al. 1986). The insertion site of the five AGG codons within the lacZ gene is indicated.

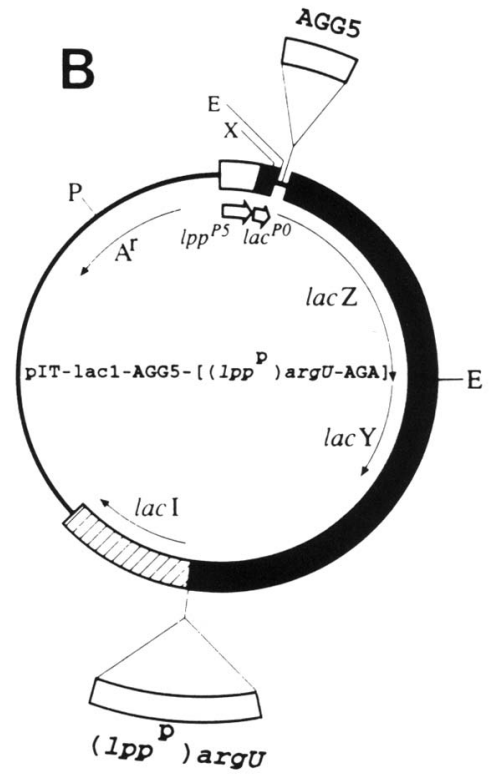

tRNA becomes extremely limited as cell growth reaches the stationary phase. As a result, the expression of primary target genes becomes inhibited by having the AGA/AGG codon very close to the initiation codon. This hypothesis, as designated the minor codon modulator hypothesis (Inouye and Chen 1990), is supported by the fact that the overexpression of tRNA for the minor

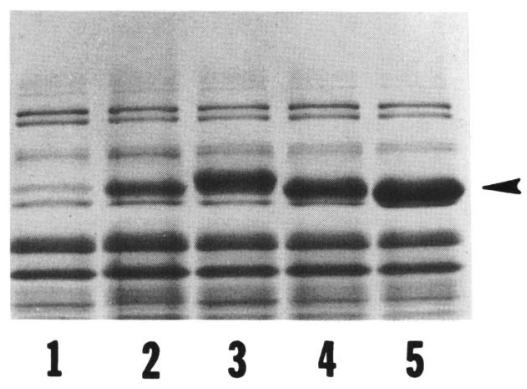

Figure 4. Detection of $\beta$-galactosidase produced under different conditions by SDS-PAGE. $E$. coli cells harboring different plasmids were grown for $22 \mathrm{hr}$ after the addition of $2 \mathrm{mM}$ IPTG. SDS-PAGE was carried out as described in Materials and methods. (Lane 1) Cells harboring pIT-lacl-AGG5; (lane 2) pITlacl-AGG5 [(lpp $\left.\left.p^{p}\right) \arg U\right]$; (lane 3) pIT-lacl-AGG5 with eight linkers (Chen and Inouye 1990); (lane 4) pIT-lacl-CGU5; (lane 5) pIT-lac1 as a control. The arrowhead indicates the position of $\beta$-galactosidase production by pIT-lacl (lane 5 ). Note that $\beta$-galactosidase in other lanes migrated slower than that in lane 5 because of its larger sizes. codons is able to overcome the inhibitory effect by the minor codons.

The genes listed in Table 1 are likely to be the primary



Figure 5. Production of tRNAArg $\mathrm{UCO}_{\mathrm{UCU}}$. The tRNA fraction was isolated, electrophoresed, and hybridized as described in Materials and methods. (Lane 1) The tRNA preparation was from cells harboring pIT-lacl-AGG5; (lane 2) tRNA from cells harboring pIT-lacl-AGG5 [(lpp $)^{p}$ argU-AGA]. After washing off the probe for tRNA $\mathrm{AgE}_{\mathrm{U}}$ from the filter, 5'-TTTTCAATCCCCTGCTC-3', which is complementary to the anticodon loop of tRNA ${ }^{\text {Phe }}$, was used for the same filter as a control to detect tRNA ${ }^{\text {Phe }}$. Both lanes 1 and 2 showed almost identical hybridization signals (data not shown), indicating that both RNA preparations contained the same amount of tRNA. 
A


Figure 6. Incorporation of $\left[{ }^{35} \mathrm{~S}\right]$ methionine into $\beta$-galactosidase during different growth phases. $|A| E$. coli cells harboring either pIT-lacl or pIT-lacl-AGG5 were labeled with $\left[{ }^{35}\right.$ S $]$ methionine for $10 \mathrm{~min}$ under various growth phases as described in Materials and methods. Times when the labeling was carried out are indicated at the top of the lanes in hours. $(B)$ The effects of tRNA ${ }_{U C U}^{\mathrm{Arg}}$ and tRNA $\mathrm{Crg}_{\mathrm{CCU}}^{\mathrm{Arg}}$ on the production of $\beta$-galactosidase with five AGG codons were examined at 3 and $5 \mathrm{hr}$ of cell growth. Cells were labeled as described in $A$. Plasmids used were pIT-lacl-AGG5 for LacZ(AGG) $\left.\right|_{5}$, pIT-lac1 for LacZ (control), pIT-lacl-AGG5 [(1pp $\left.p^{p} \arg U-A G A\right]$ for tRNA(AGA), and pIT-lacl-AGG5 [(lpp $p^{p}$ argU-AGG] for tRNA(AGG). The total cell extracts were analyzed by SDS-PAGE as described in $\mathrm{Ma}$ terials and methods. Arrows in both $A$ and $B$ indicate the position of $\beta$-galactosidase.

target genes regulated by the proposed model. Interestingly, these genes are highly diverse in their functions, including DNA synthesis, protein synthesis, gene regulation, and metabolic activities. Although individual genes are considered to be regulated by different mechanisms at various levels such as transcription, translation, and protein stability, their expression may also be regulated at the level of translation during the stationary phase by the mechanism proposed in this paper. Thus, the proposed regulatory mechanism by the AGA/AGG minor codons plays an important role in global gene expression of $E$. coli by regulating a number of key genes at the same time when cellular growth becomes limited.

\section{Possible molecular mechanisms}

The molecular mechanism of the minor codon modulator hypothesis is postulated in Figure 9. The rate of the synthesis of a protein is determined by the rate of translation initiation $\left(R_{\mathrm{i}}\right)$ and the rate of the speed of a ribosome moving along mRNA. The speeds of decoding of major codons $\left(r_{\mathrm{a}}\right)$ have been shown not to be significantly different from those of minor codons $\left(r_{b}\right)$ in exponentially growing cells of $E$. coli so that a queue of ribosomes is unlikely to be formed at minor codons (Sørensen et al. 1990). However, when tRNAArg $A$ ACCU becomes limited under certain conditions, $r_{\mathrm{b}}$ for an AGA/AGG codon becomes much slower than $r_{a}$ causing ribosome stalling at the minor codon. As a result, a queue of ribosomes is formed in front of the minor codon (see Fig. 9, II). The number of ribosomes in the queue is determined by how slow $r_{\mathrm{b}}$ is in comparison with $r_{\mathrm{a}}$ and, in turn, by the availability of the tRNA. If the position of the minor codon is far away from the initiation codon, the queue formation does not reach to the initiation codon (Fig. 9, II) so that the rate of protein synthesis from the gene is not affected by the limited amounts of the tRNA and is determined by the rate of initiation, $R_{\mathrm{i}}$ in both cases, I and II (Fig. 9). However, as the position of the minor codon is nearby the initiation codon as shown in Figure 9, III, the queue formation blocks the entry of a ribosome, and thus the rate of protein synthesis in this case is determined by $r_{\mathrm{b}}$.

Our results indicate that if the site of the minor codons is $\sim 60$ codons away from the initiation codon, which corresponds to a size of five ribosomes (about 12 codons per ribosome; Gold et al. 1981), the inhibitory effect by the queue formation is eliminated quite effectively (Chen and Inouye 1990). This suggests that under the condition used in this study, the queue was not formed by more than four ribosomes. The overproduction of tRNA Arg did not fully resume the $\beta$-galactosidase production to the control level in the experiment shown in Figure 2. The reason for this result is unknown at present. However, it is possible that the tRNA produced under the present condition was not fully active because of incomplete processing and/or modification of the tRNA molecule.

The closer the AGA/AGG codon is to the initiation codon, the more effective the translation blockage is likely to be. Most of the primary target genes listed in Table 1 contain the minor codon within the first 10 codons (see also Fig. 8). The fact that the blockage can be released gradually as the minor codons are positioned farther away from the initiation codon /Chen and Inouye 1990 ) suggests that the regulations of primary target genes are subtly different for individual genes, depending on the position of the minor codon. It should be noted that in our experimental system, we exaggerated the effect of the minor codons by inserting five AGG codons. However, we have shown earlier that the insertion of even a single AGG codon caused significant reduction in $\beta$-galactosidase activity (Chen and Inouye 1990). In addition to the AGA/AGG codons for arginine, other minor codons for other amino acids are also preferentially used near the initiation codon (Chen and Inouye 1990; Eyre-Walker and Bulmer 1993). Therefore, even if there is only one AGA/AGG codon within the first 25 codons in a given primary target gene, it may have other additional minor codons in this region. There are numerous examples for the existence of many minor codons within the first 25 codons, such as, IHF [Ser-4 (TCA), Ile-7 (ATA), Arg-9 (AGA), Pro-18 (CCC)] (Flamm and Weisberg 1985), phenylalanyl-tRNA synthetase $\beta$-subunit [Arg-2 (AGG), Ser-6 (TCA), Ser-14 (AGT), Ser-23 (TCA)] (Mechulam et al. 1985), adenylate cyclase [Arg-11 (AGA), 
Figure 7. Two-dimensional gel electrophoresis of proteins from $E$. Coli JM83 without or with the $\arg U$ gene. Cells were grown and labeled at $\mathrm{l} \mathrm{hr}$ (mid-exponential phase) and $10 \mathrm{hr}$ (late stationary phase) with $\left[{ }^{35} \mathrm{~S}\right] \mathrm{me}$ thionine as described in Materials and methods. Two-dimensional gel electrophoresis was carried out using $2 \%(\mathrm{pH} 3.5-10) \mathrm{am}$ pholines for the first dimension and $11.5 \%$ acrylamide for the second dimension (VanBogelen et al. 1990). (A) E. coli JM83 with pIT-lacl-AGG5 at $1 \mathrm{hr} ;(B) E$. coli JM83 with pIT-lacl-AGG5 [(lpp $\left.{ }^{P} \mid \arg U-\mathrm{AGA}\right]$ at 1 $\mathrm{hr}_{;}(C)$ E. coli JM83 with pIT-lacl-AGG5 at $10 \mathrm{hr}$; and $(D) E$. coli JM83 with pIT-lac1AGG5 [(lpp $\left.{ }^{P}\right)$ arg U-AGA] at $10 \mathrm{hr}$. Those proteins that were overproduced in $D$ are circled.
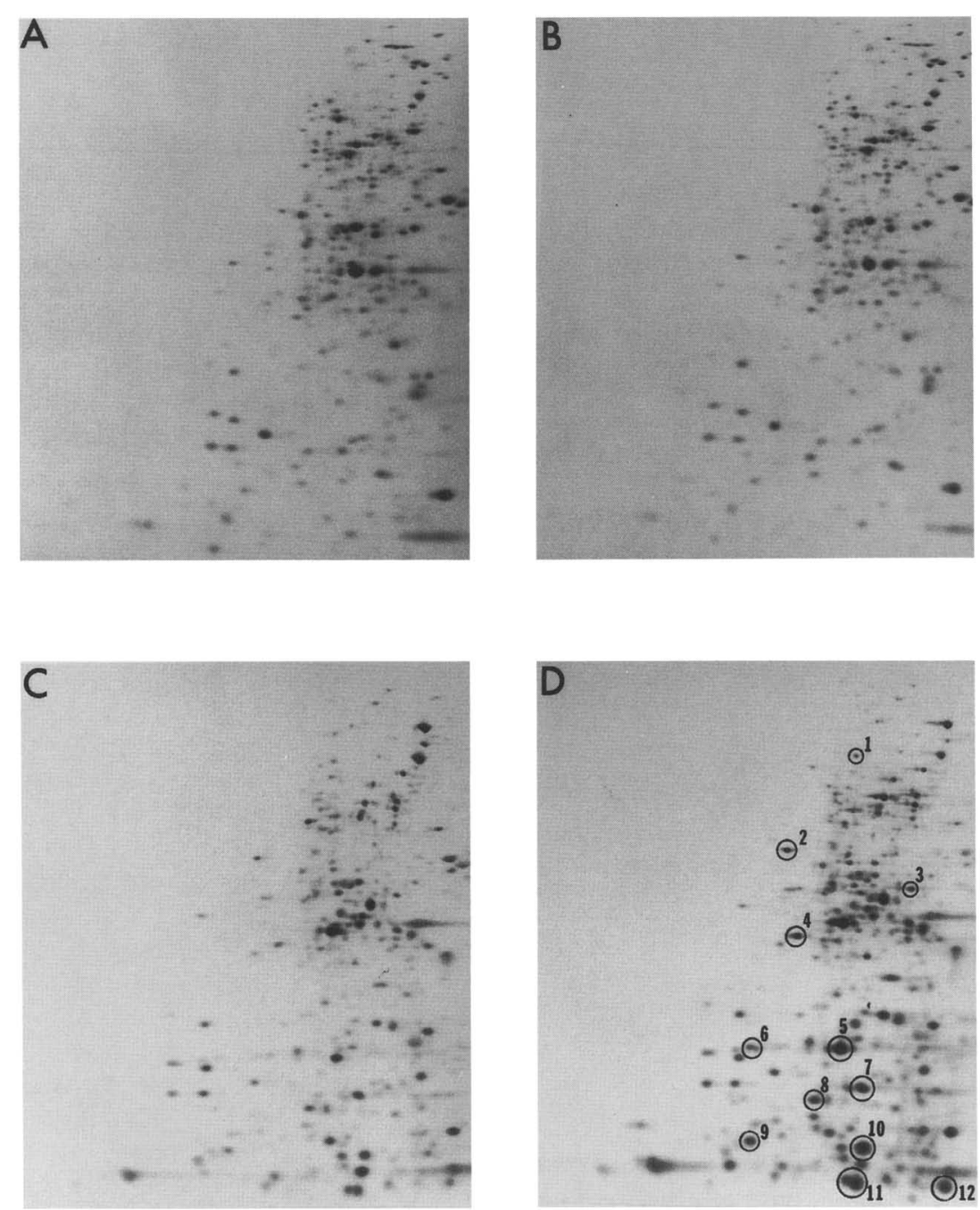

Ile-15 (ATA) (Aiba et al. 1984), succinate dehydrogenase C [Ile-2 (ATA), Arg-3 (AGA), Arg-9 (AGA), Leu-15 (CTA), Pro-21 (CCC), Ile-25 (ATA)] (Wood et al. 1984), ribonuclease P [Pro-7 (CCC), Arg-8 (AGG), Pro-15 (CCC), Ser-16 (AGT), Thr-19 (ACA)] (Hansen et al. 1985), and EnvZ [Arg-2 (AGG), Ser-10 (AGT), Ser-11 (TCA)] (Mizuno et al. 1982). Therefore, the minor codons for arginine as well as for other amino acids existing in various key functional genes play an important role in global gene regulation in $E$. coli under stress conditions such as nutrient limitation.

It has been shown that synonymous codon usage is less biased at the start of $E$. coli genes than elsewhere (Bulmer 1988; Eyre-Walker and Bulmer 1993). In particular, those genes highly expressed use minor codons preferentially near the initiation codon. These investigators proposed that preferential selection of minor codons at the start region is to avoid or minimize the amount of secondary structures at the start of the mRNA for more efficient translation initiation. However, these investigators did not present any examples in which a substitution of a minor codon near the start site of a mRNA with its synonymous major codon creates a stable secondary structure. We argue that their proposal is highly unlikely for the following reasons, although in some

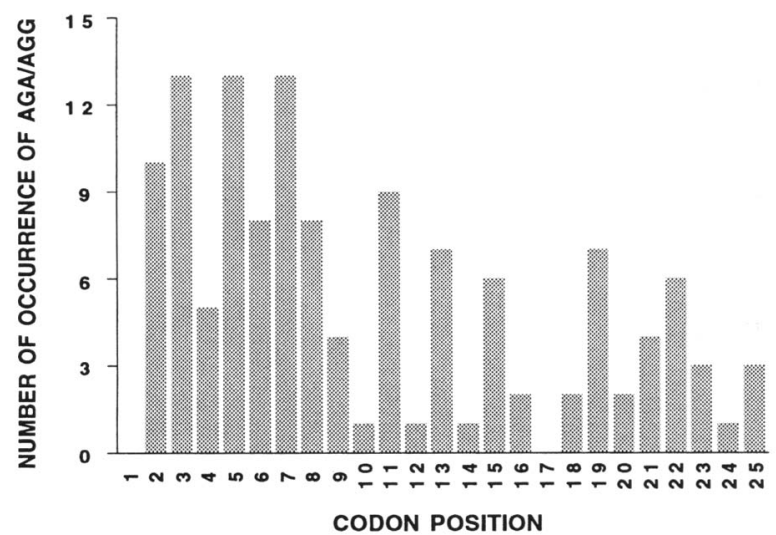

Figure 8. Distribution of AGA/AGG codons within the first 25 codons in the 129 E. coli genes that contain a single AGA/ AGG codon within the first 25 codons. 


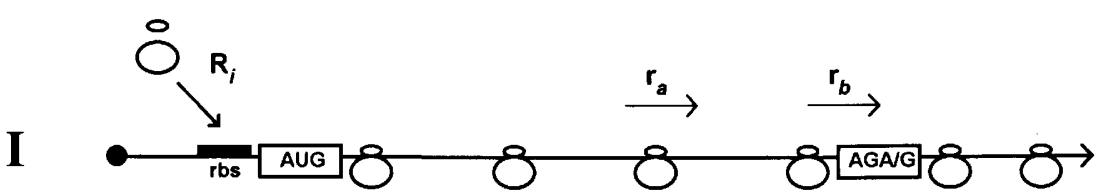

II
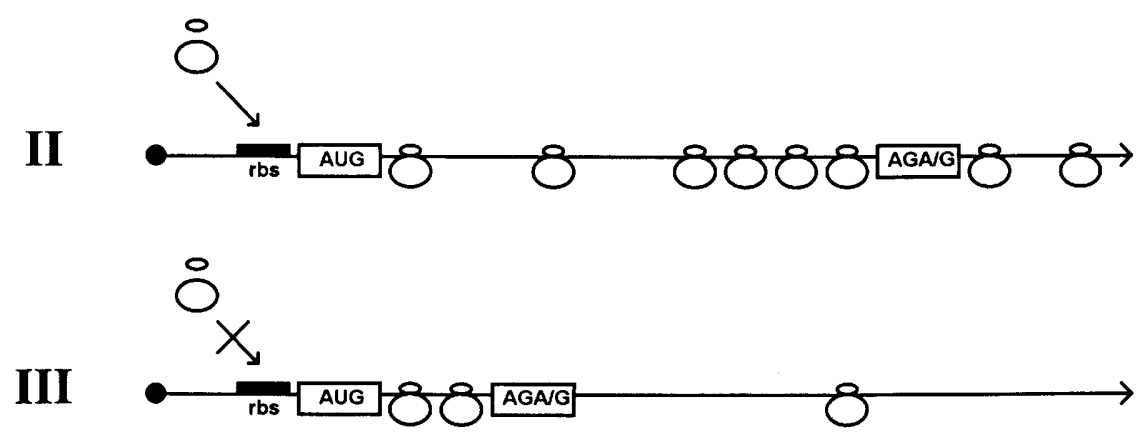

Figure 9. Effect of the positions of an AGA/AGG codon in an mRNA on its translational efficiency. $(I)$ Under a normal growth condition. A ribosome initiates translation entering at the ribosome binding site (rbs) at a rate of $R_{\mathbf{i}}$. The ribosomes are then translated in the mRNA /solid line) by decoding major codons at a rate of $r_{\mathrm{a}}$ and minor codons at a rate of $r_{\mathrm{b}}$. (II) Under a growth-limiting condition, $r_{\mathrm{b}}$ becomes much slower than $r_{\mathrm{a}}$, resulting in the formation of a queue of ribosomes at the AGA/AGG minor codon. Note that because the minor codon is away from the AUG initiation codon, the queue does not block the entry of a ribosome. (III) In the case of the minor AGA/AGG codon locating very close to the initiation codon, the queue reaches the initiation codon, which then inhibits the entry of a ribosome. cases the usage of minor codons accidentally eliminates the formation of a secondary structure. First, our experimental results demonstrate clearly that the existence of minor codons near the start site reduces the gene expression. Note that as discussed above, the existence of a single AGG codon is enough for the effect /Chen and Inouye 1990). Second, this effect is not the result of the formation of a secondary structure, because it is growthphase dependent and, most importantly, can be overcome by the overproduction of tRNA (this paper). The effect of the tRNA overproduction described here cannot be explained by the secondary structure hypothesis by Eyre-Walker and Bulmer (1993). Third, introduction of extensive secondary structures near the start site by inserting tandem repeat sequences does not reduce gene expression (Chen and Inouye 1990). On the contrary, these insertions dramatically reduce the negative effect of minor codons on gene expression by further moving the minor codons away from the initiation codon /Chen and Inouye 1990).

\section{Materials and methods}

\section{Bacterial strains and plasmids}

E. coli strain $\mathrm{SB} 4288\left[\mathrm{~K}-12 \mathrm{~F}^{-}\right.$recA thi-1 relA mal-24 spcl2 supE-50 DE5 $\Delta($ lac-proB)] (Green and Inouye 1984) and JM83 [ara $\Delta\left(\right.$ lac-proAB) rpsL $\Phi 80$ lacZ $\Delta M 15 \mathrm{relA}^{+}$] (Yanisch-Perron et al. 1985) were used. The plasmid pIT-lacl-AGG5 was constructed from pIT-lacl as described previously /Chen and Inouye 1990). The arg $U$ gene was constructed as follows: The entire Arg-tRNA coding region was synthesized according to the sequence of tRNA for arginine (Garcia et al. 1986) by six oligonucleotides (see Fig. 3A). The 83-bp fragment thus constructed contained HindIII sites at both the $5^{\prime}$ and $3^{\prime}$ ends, which was inserted into the HindIII site of pIN III-lpp p5 $-\mathrm{A} 3$ (Inouye and Inouye 1985). The plasmid with the right orientation and sequence was then screened by DNA sequencing; subsequently, the 90-bp EcoRI-BamHI was inserted into the unique EcoRI and BamHI sites of pGFIB1 (Normanly et al. 1986). The plasmid thus obtained was designated pGF [(Ipp $\left.\left.p^{\mathrm{P}}\right) \arg U\right]$, in which the synthetic $\arg U$ gene is flanked by the synthetic Ipp promoter at the $5^{\prime}$ end and the synthetic $\operatorname{rrnC}$ transcriptional termination signal at the $3^{\prime}$ end. By PvuII digestion of pGF $\left[\left(1 p p^{p}\right) \arg U\right]$, the $377-\mathrm{bp}$ fragment containing the $\arg U$ gene with the $1 p p$ promoter and the $r r n C$ terminator was inserted into the unique SalI site of pIT-lacl /Chen and Inouye 1990), which was filled into blunt ends by the Klenow fragment of DNA polymerase I. This resulted in pIT-lacl-AGG5 [(lpp $\left.\left.p^{p}\right) \arg U-\mathrm{AGA}\right]$ and pIT-lacl-AGG5 [(lpp $\left.\left.p^{p}\right) \arg U-\mathrm{AGG}\right]$ (see Fig. 3A,B).

\section{Protein analysis}

Cells harboring various plasmids were grown at $37^{\circ} \mathrm{C}$ in $\mathrm{M} 9$ medium supplemented with casamino acids (Miller 1972). At a Klett unit of 25, isopropyl- $\beta$-D-thiogalactopyranoside (IPTG) was added to a final concentration of $2 \mathrm{~mm}$. Aliquots were taken at time intervals after the addition of IPTG, and $\beta$-galactosidase activity was assayed by the procedure of Miller (1972). The production of $\beta$-galactosidase was analyzed by SDS-PAGE as described previously (Chen and Inouye 1990). The gels were stained by Coomassie brilliant blue.

\section{Labeling experiments}

E. coli strain JM83 containing different plasmids was grown at $37^{\circ} \mathrm{C}$ in $\mathrm{M} 9$ medium supplemented with glucose $(0.2 \%)$, proline $(20 \mu \mathrm{g} / \mathrm{ml})$, and ampicillin $(50 \mu \mathrm{g} / \mathrm{ml})$. The overnight culture was diluted 30 -fold with fresh M9 medium supplemented, as described above, except that the concentration of glucose was $0.4 \%$. The diluted culture was incubated at $37^{\circ} \mathrm{C}$ until the Klett reading reached 40 ; IPTG was then added to a final concentration of $2 \mathrm{~mm}$. At a certain time point after the addition of IPTG, $1 \mathrm{ml}$ of the cell culture was taken out and $\left[{ }^{35} \mathrm{~S}\right]$ methionine (Trans ${ }^{35}$ S-label, ICN) was added to a final concentration of 50 $\mu \mathrm{Ci} / \mathrm{ml}$. After $10 \mathrm{~min}$, nonradioactive methionine was added to a final concentration of $200 \mu \mathrm{g} / \mathrm{ml}$. The cells were collected by centrifugation and washed once with $20 \mathrm{~mm}$ phosphate buffer (pH 7.0). The pelleted cells were then heated at $100^{\circ} \mathrm{C}$ for $3 \mathrm{~min}$ in $100 \mu \mathrm{l}$ of $10 \mathrm{~mm}$ sodium phosphate buffer containing $1 \%$ SDS and $5 \%$ glycerol; solublized proteins were analyzed by $10 \%$ SDS-polyacrylamide gel (SDS-PAGE). SDS-PAGE was performed according to the procedure described by Laemmli (1970). Two-dimensional gel electrophoresis was carried out according to VanBogelen et al. (1990). After electrophoresis, the gels were dried and autoradiographed at $-70^{\circ} \mathrm{C}$ with Kodak X-Omat $\mathrm{AR}$ films. 


\section{Isolation and Northern analysis of $t R N A$}

Isolation of tRNA was carried out as described (Wittwer and Stadtman 1986). Briefly, E. coli cells were harvested from a 10$\mathrm{ml}$ culture by centrifugation, washed once with buffer $\mathrm{A}[20 \mathrm{mM}$ sodium acetate, $10 \mathrm{mM} \mathrm{MgCl}_{2}, 1 \mathrm{~mm}$ dithiothreitol (DTT) at $\mathrm{pH}$ 5.0], and resuspended in $1 \mathrm{ml}$ of buffer A. RNA was then extracted with $1 \mathrm{ml}$ of $88 \%$ phenol for $1 \mathrm{hr}$ with occasional vortex. After addition of $0.2 \mathrm{ml}$ of $5 \mathrm{M} \mathrm{NaCl}$, the mixture was centrifuged to separate phases. Two volumes of ethanol were added to the aqueous phase. After standing overnight at $-20^{\circ} \mathrm{C}$, the precipitate was collected by centrifugation, dissolved in $1 \mathrm{ml}$ of buffer $\mathrm{A}$, and applied to a small $(0.3 \mathrm{ml})$ column of DEAEcellulose (DE-52, Whatman) equilibrated with buffer $A$. The column was washed with $1 \mathrm{ml}$ of buffer $A$ containing $0.3 \mathrm{M} \mathrm{NaCl}$, and the tRNA fraction was eluted with $1 \mathrm{ml}$ of $1 \mathrm{M} \mathrm{NaCl}$ in buffer $A$. The tRNA fraction thus prepared was separated on a $20 \%$ polyacrylamide gel. The ratio of acrylamide to bisacrylamide was 19:1. Electrophoresis was carried out at $145 \mathrm{~V}$ for 20 $\mathrm{hr}$ at $4^{\circ} \mathrm{C}$ in TBE $(26.7 \mathrm{mM}$ Tris- $\mathrm{HCl}, 26.7 \mathrm{~mm}$ boric acid, and $0.752 \mathrm{mM}$ EDTA at $\mathrm{pH} 8.3$ ). After electrophoresis, the gels were soaked in $250 \mathrm{ml}$ of transfer buffer $(80 \mathrm{mM}$ Tris- $\mathrm{HCl}, 118 \mathrm{~mm}$ boric acid, and $2.4 \mathrm{mM}$ EDTA at $\mathrm{pH} 8.3$ ) for $15 \mathrm{~min}$. MagnaGRAPH nylon membranes (ISS-Enprotech, Natick, MA) were used in a semidry electroblotter for the transfer. The tRNAspecific probe used was a 16-mer synthetic DNA oligonucleotide complementary to the anticodon loop of tRNA Arg ${ }_{\mathrm{UC}}^{\mathrm{Arg}} 5^{\prime}$ CCCACGACTTAGAAGG-3'.

\section{Enzymes and chemicals}

Restriction enzymes were obtained from New England Biolabs. IPTG was purchased from Sigma Chemical Co. DNA oligomers were synthesized on an Applied Biosystems 380B DNA synthesizer.

\section{Acknowledgments}

We are grateful to Drs. Lynne Vales and Pamela Jones for critical reading of the manuscript. The present work was supported by a grant from the U.S. Public Health Service (GM 19043).

The publication costs of this article were defrayed in part by payment of page charges. This article must therefore be hereby marked "advertisement" in accordance with 18 USC section 1734 solely to indicate this fact.

\section{References}

Aiba, H., K. Mori, M. Tanaka, T. Ooi, A. Roy, and A. Danchin. 1984. The complete nucleotide sequence of the adenylate cyclase gene of Escherichia coli. Nucleic Acids Res. 12: 9427-9440.

Anderson, S.G.E. and C.G. Kurland. 1990. Codon preferences in free-living microorganisms. Microbiol. Rev. 54: 198-210.

Bulmer, M. 1988. Codon usage and intragenic position. J. Theor. Biol. 133: 67-71.

Chen, G.T. and M. Inouye. 1990. Suppression of the negative effect of minor arginine codons on gene expression; preferential usage of minor codons within the first 25 codons of the Escherichia coli genes. Nucleic Acids Res. 18: 1465-1473.

Eyre-Walker, A. and M. Bulmer. 1993. Reduced synonymous substitution rate at the start of enterobacterial genes. $\mathrm{Nu}$ cleic Acids Res. 21: 4599-4603.

Flamm, E. and R.A. Weisberg. 1985. Primary structure of the hip gene of Escherichia coli and of its product, the beta-subunit of integration host factor. I. Mol. Biol. 183: 117-128.

Garcia, G.M., P.K. Mar, D.A. Mullin, J.R. Walker, and N.E. Prather. 1986. The Escherichia coli dnaY gene encodes an arginine transfer RNA. Cell 45: 453-459.

Gold, L., D. Pribnow, T. Schneider, S. Shinedling, B.S. Singer, and G. Stromo. 1981. Translational initiation in prokaryotes. Annu. Rev. Microbiol. 35: 365-403.

Green, P.J. and M. Inouye. 1984. Roles of the $5^{\prime}$ leader region of the ompA mRNA. J. Mol. Biol. 176: 431-442.

Hansen, F.G., E.B. Hansen, and T. Atlung. 1985. Physical mapping and nucleotide sequence of the mpA gene that encodes the protein component of ribonucleases $\mathrm{P}$ in Escherichia coli. Gene 38: 85-93.

Ikemura, T. 1981a. Correlation between the abundance of Escherichia coli transfer RNAs and the occurrence of the respective codons in its protein gene. J. Mol. Biol. 146: 1-2l.

. 1981b. Correlation between the abundance of Escherichia coli transfer RNAs and the occurrence of the respective codons in its protein genes: A proposal for a synonymous codon choice that is optimal for the $E$. coli translational system. J. Mol. Biol. 151: 389-409.

Inouye, M. and G. Chen. 1990. Regulation of gene expression by minor codons in Escherichia coli: Minor codon modulator hypothesis. NATO ASI Ser. H 49: 217-225.

Inouye, S. and M. Inouye. 1985. Up-promoter mutations in the lpp gene of Escherichia coli. Nucleic Acids Res. 13: 3101-3110.

Kiesewetter, S., F. Wolfgang, and M. Sprinzl. 1987. Sequences of three minor tRNA ${ }^{\text {arg }}$ from E. coli. Nucleic Acid Res. 15: 3184.

Laemmli, U.K. 1970. Cleavage of structural proteins during the assembly of the head of bacteriophage T4. Nature 227: 680685.

Maruyama, T., T. Gojobori, S.I. Aota, and T. Ikemura. 1986. Codon usage tabulated from the Genbank genetic sequence data. Nucleic Acids. Res. 14: r151-r197.

Mechulam, Y., G. Fayat, and S. Blanquet. 1985. Sequence of the Escherichia coli pheST operon and identification of the himA gene. J. Bacteriol. 163: 787-791.

Miller, J.H., ed. 1972. Experiments in molecular genetics, pp. 352-355. Cold Spring Harbor Laboratory, Cold Spring Harbor, New York.

Mizuno, T., E.T. Wurtzel, and M. Inouye. 1982. Osmoregulation of gene expression: II. DNA sequence of the envZ gene of the ompB operon of Escherichia coli and characterization of its gene product. J. Biol. Chem. 257: 13692-13698.

Normanly, J., J.M. Masson, L.G. Kleina, J. Abelson, and J.H. Miller. 1986. Construction of two Escherichia coli amber suppressor genes: tRNA cua and tRNA cua. Proc. Natl. Acad. Sci. 83: 6548-6552.

Sørensen, M.A., C.G. Kurland, and S. Pedersen. 1989. Codon usage determines translation rate in Escherichia coli. J. Mol. Biol. 207: 365-377.

Sørensen, M.A., K.F. Jensen, and S. Pedersen. 1990. Measurements of translation rates in vivo of individual codons and implication of the observed rate difference for gene expression. NATO ASI Ser. H 49: 207-216.

VanBogelen, R.A., M.E. Hutton, and F.C. Neidhardt. 1990. Gene-protein database of Escherichia coli K-12: Edition 3. Electrophoresis 11: 1131-1166.

Wittwer, A.J. and T.C. Stadtman. 1986. Biosynthesis of 5-Methylaminomethyl-2-Selenouridine, a naturally occurring nucleoside in Escherichia coli tRNA. Arch. Biochem. Biophys. 248: 540-550.

Wood, D., M.G. Darlison, R.J. Wilde, and J.R. Guest. 1984. Nucleotide sequence encoding flavoprotein and hydrophobic subunits of the succinate dehydrogenase of Escherichia coli. Biochem. J. 222: 519-534.

Yanisch-Perron, C.J. Viera, and J. Messing. 1985. Improved M13 phage cloning vectors and host strains: Nucleotide sequences of the M13mp18 and puc19 vectors. Gene 33: 103-119. 


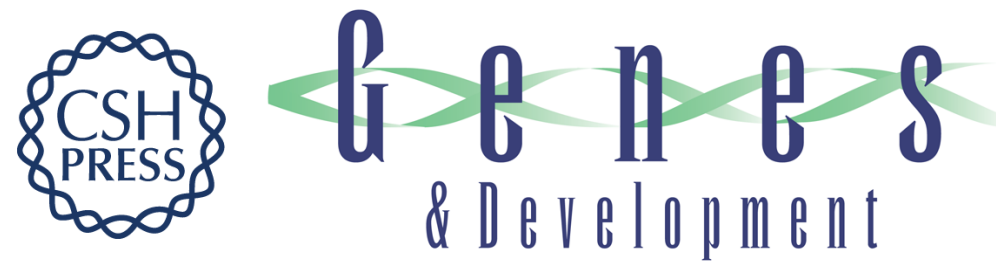

\section{Role of the AGA/AGG codons, the rarest codons in global gene expression in Escherichia coli.}

G T Chen and M Inouye

Genes Dev. 1994, 8:

Access the most recent version at doi:10.1101/gad.8.21.2641

References This article cites 26 articles, 5 of which can be accessed free at:

http://genesdev.cshlp.org/content/8/21/2641.full.html\#ref-list-1

License

Email Alerting

Service

Receive free email alerts when new articles cite this article - sign up in the box at the top right corner of the article or click here.

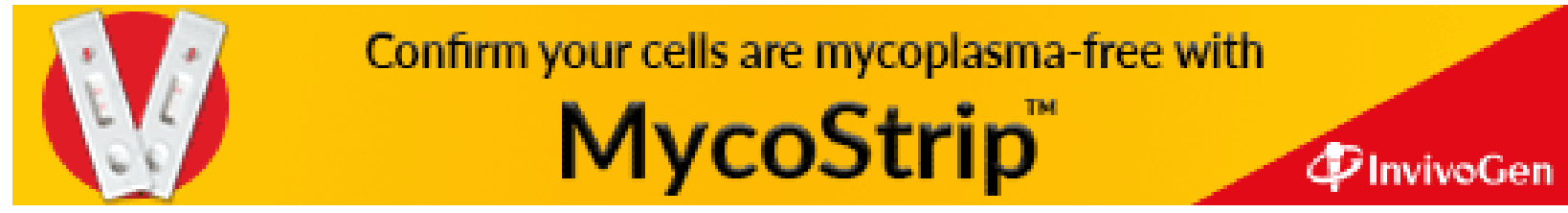

